\title{
$\gamma$-Glutamyl 誘導体の代謝とその生理的意義
}

\author{
葛 西 隆 則 Takanori KASAI \\ 北海道大学農学部
}

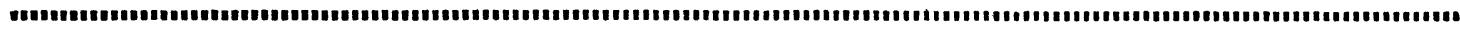

現在までに, 70 種類以上の $\gamma$-glutamy1 誘導体（以 下 $\gamma$-Glu 誘導体と略)一一元の大部分は高等植物および 担子菌類由来一が見いだされている. しかし, 代謝お よび生理的意義の知られているものは, 代表的な $\gamma-\mathrm{Glu}$ 誘導体であるグルタチオンを含めわずかしかない. した がって，大きな標題を揭げたにもかかわらず，代謝，意 義, 作用などの判明している $r$-Glu 誘導体を単に羅列 することしかできないのが現状である. 大部分の $r-G 1 u$ 誘導体は, 単離構造決定はされているが, その代謝, 意義 などは不明のため，テーマと紙数の関係からここでは触 れないので, $r-G 1 u$ 誘導体の総説とはなりえず，特に動 物起原のものについてはわずかしか記載できないことを 予めおことわりしたい. グルタチオンとその誘導体につ いてもほとんど触れないが，それらについてはWaley(1) の総説に他の天然ペプチドとともに詳述されている. 高 等植物, 担子菌類中の $\gamma-G 1 u$ 誘導体についても, 近く総 説(2)が出される. Bacillus 属の菌のカプセルは polyr-glutamic acid（しばしばD-型を多量含む）といら興 味ある構造を有するが，その化学および免疫化学につい ては Nitecki と Goodman(3) の総説に詳しい.

\section{1. $\boldsymbol{r}$-Glu 誘導体の分布}

植物では, 大部分の $\gamma-\mathrm{Glu}$ 誘導体はマメ科, ユリ科, および担子菌類から見いだされている. 含硫アミノ酸お よびその $r-G l u$ 誘導体はユリ科に特徴的であり, それ らについては後述する [4 章 3$)$ 参照]. マメ科植物から の $\gamma$-Glu 誘導体の報告が多いのは, マメ科植物が食品 としての重要性, 毒性などの理由により他の科の植物よ
りも精力的に研究されていることを考慮しなければなら ない. 蛋白性アミノ酸の $\gamma-$ Glu 誘導体と非蛋白性アミ ノ酸の $\gamma$-Glu 誘導体が共存している場合もあるし, 一 方のみの場合もある. 共存する $r$-Glu 誘導体間の濃度 差も大きく，たとえば Fagus silvatica（ブナ）の種子 では, $r$-Glu・alanine の含量は最も含量の高い $r$-Glu・ phenylalanine の 6 千分の 1 である(4). しかし, 分析法 が進歩すればすべての $\gamma$-Glu 誘導体がすべての種から 見いだされると信ずべき根拠はない，たとえば，非常に 多量の Beta vulgaris (ビート) を用いた詳細な研究で 見いだされた $r$-Glu 誘導体は，少量の $\gamma$-Glu·r-aminobutyric acid のみであった(5).

遊離アミノ酸とその $r$-Glu 誘導体の間にはもちろん 関係があるであろらが，その濃度間には簡単な相関はな

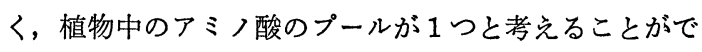
きないことを示している.

植物中の $\gamma-$ Glu 誘導体の大部分は, 種子から見いだ されている. これは, 種子が入手しやすいこと, また経 済的に重要であることから他の部位よりもよく研究され ているといらこともあるが， $r-G l u$ 誘導体执よび非蛋白 性アミノ酸は種子に著量蓄積し, 新鮮部には低濃度しか, あるいはまったく存在しないという一般的傾向をあらわ してもいる. 高等植物で種子その他の貯蔵組織以外の部 位から見いだされた $\gamma-\mathrm{Glu}$ 誘導体の例としては, Iris tingitana (アイリス) の全組織中に $\gamma$-Glu -alanine, $\gamma$ Glu. $\beta$-alanine, $\gamma$-Glu. $\beta$-aminoisobutyric acid(6) Pisum sativum (エンドウ) の実生から多量の $\gamma-\mathrm{Glu} \cdot \mathrm{D}-$ alanine $\mathrm{e}^{(7)}$ が, Fagus silvatica (赤ブサ) 実生から $\gamma$ - 
Glu·leucine と $r$-Glu·isoleucine ${ }^{(8)}$ が報告されている. linatine[4 章8)参照] は Linum usitatissinum (覀麻) の全部位に(9), テアニンも Camellia sinensis (茶) の 果実を除く全部位に存在する [4 章 7 )参照 ${ }^{(10)}$. 動物起 原のものとしては, ウシやサルの脳(11,12), およびヒトの 尿(13)などに多数の $\gamma$-Glu 誘導体の存在が知られている. Musca 属のイエバエ幼虫に含まれる多量の $\gamma-\mathrm{Glu} \cdot \mathrm{ph}$ enylalanine については 4 章 5 )を参照されたい.

\section{1）蛋白性アミノ酸の $\boldsymbol{\gamma}$-Glu 誘導体}

蛋白性アミノ酸のうち $\gamma-$ Glu 誘導体として見いださ れていないのはリジン，ヒスチジン，プロリンであるが， 前二者の $\gamma-\mathrm{Glu}$ 誘導体は中性であり, その単離が酸性 物質の場合よりもはるかに困難であるためにすぎないの かもしれない. $\gamma$-Glu·proline は報告されていないが, r-Glu·pipecolic acid は Gleditsia caspica より単離さ れており (14), 植物が 2 級のアミノ基を有するアミノ酸の $\gamma$-Glu 誘導体を合成しらることはわかっている．植物中 ではフェニルアラニン, チロシン, ロイシン, メチオニ ンなどの疎水性アミノ酸の $r-G 1 u$ 誘導体の分布の広い 点が注目される.

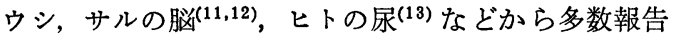
されている動物起原の $\gamma-\mathrm{Glu}$ 誘導体の大部分は, 蛋白 性アミノ酸をC端アミノ酸として有している.

2）非蛋白性アミノ酸およびアミンの $\boldsymbol{\gamma}$-Glu 誘遵体 ここに属する化合物は大部分が高等植物拉よび担子菌 類由来のものであり, ほとんどの場合遊離型と共存して いる. その場合でも, ある種では結合型の含量のほうが 多いが，それに近縁の別の種では遊離型のほらが多量含 まれている, という例も多く, その間に簡単な相関関係 の認められないことは先述の通りである.たとえば, Acacia georginae 種子では $\gamma$-Glu·djenkolic acid 濃 度は遊離の djenkolic acid よりも高いが, A. suberosa ではこれと逆の関係にある(15).

ここに属する $\gamma$-Glu 誘導体のうち, 生理的意義, 作 用などが判明しているものについては後述する.

\section{2. $\boldsymbol{\gamma}$-Glu 誘導体を指標化合物とした化学分類}

$\gamma$-Glu 誘導体は，化学分類に打ける指標化合物の 1 つ として用いられている. Lathyrus 属は種子中の $\gamma-\mathrm{Glu}$ ・ $\beta$-aminopropionitrile その他のニンヒドリン反応陽性物 質の有無により(16)，またVicia 属は $\gamma$-Glu· $\beta$-cyano- alanineを1つの指標として ${ }^{(17)}$ 数グループに分けられる. Vigna mungo と V.radiata は，種子中に前者は $r$ Glu.S-methylcysteine とその sulfoxide を, 後者は $\gamma$-Glu·methionine とその sulfoxideを多量含むことか ら明確に区別できる(18). マメ科に属する栽培作物を，種 子中の $\gamma$-Glu 誘導体を指標として 3 群に大別する試み がある(19). $\gamma$-Glu.phenylalanine と $\gamma$-Glu-tyrosine を多量含むグループには Glycine max (大豆), Medicago sativa（アルファルファ）などの油用あるいは飼料作物 が，またこの 2 つの $r$-Glu 誘導体をほとんど含まない が他の r-Glu 誘導体を多量含むグループにはPhaseolus vulgaris (インゲン豆), P.radiatus (緑豆) などの食 用作物が含まれる， $r$-Glu 誘導体をほとんどあるいはま ったく含まないグループに属するのは, 知られている範 囲ではVicia faba(ソラ豆) のみである.

動物界ではイエバェの幼虫段階で, Sarcophaga 属の ものは $\beta$-alanyltyrosine を, Musca 属のものは $\gamma$ Glu·phenylalanine を, Drosophila 属のものは tyrosine 0-phosphate を含む，という結果が報告されてい $ろ^{(20)}$.

\section{3. ライフサイクル中の $\boldsymbol{\gamma}$-Glu 誘導体の変化とそ れに関与する酵素}

植物のライフサイクルを通じて $\boldsymbol{\gamma}$-Glu 誘導体の变化 を定量的に追跡したデータは非常に少ない，ただ，発芽 中の変化のみについては数例の報告があり, それらによ ると, 種子などの貯蔵組織中に存在する $\gamma$-Glu 誘導体 のほとんどは発芽中消失し，成熟中に再び同組織中に蓄 積してくる（たとえば Glycine max 中の $r$-Glu・ phenylalanine その他(21), Phaseolus vulgaris 中の $\gamma$-Glu.S-methylcysteine その他(22)). 反対に, $r$-Glu 誘 導体が発芽中に増加する例もあり, 特にPisum sativum の発芽中に急激に増加する $r$-Glu・D-alanine はアラニ ン部分が D-型であることと合わせ，注目される(7). Fagus silvatica 種子中には著量の $r$-Glu·phenylalanine 他, 数種の $\gamma$-Glu 誘導体が存在するが, その実生 中にはそれらのペプチドは認められず，代りに $r-\mathrm{Glu}$ ・ leucine と $r$-Glu・isoleucine がかなり高濃度に存在す る. しかし, ロイシン残基, イソロイシン残基とも通常 の L-型である(8).

動物界では, イエバェ幼虫成長時の $\gamma$-Glu·phenylala- 
nine 含量の変化とその黒硬化との間に興味ある関係が めり, 後述する (4 章 12) 参照).

$\gamma$-Glu 誘導体の代謝に働いているとされている $\gamma-$ Glutamyltranspeptidase（以下, $\gamma$-GT と略）は, 広く 生物界に分布している. 植物では Phaseolus vulgaris 中の同醭素が詳しく研究されて括り，多くの $\alpha$-L-アミ ノ酸が $\gamma$-Glu 基の良い受容体であるが， $\beta$-および $\gamma$ アミノ酸,プロリン, アンモニアは受容体となりえない か,なってもその程度は非常に低い。また，この酵素は pH 7.5 以下では transpeptidase 活性を示さず，一方， 加水分解反応は $\mathrm{pH} 6.5$ と 9.5 の両方に最大活性を示 す(23). Asparagus officinalis 苗条からも $\gamma$-GT が精 製され，その性質が調べられている(24). しかし，同植物 からはこれまで $\gamma$-Glu 誘導体は見いだされていない。

以上に述べたことからのみでも，植物中の $\gamma$-Glu 誘 導体の生合成がすべて $\gamma$-GT の働きによると断定する には無理があると思われる. 植物からは $\gamma-\mathrm{Glu} \cdot \gamma-\mathrm{Glu}$ 結合を有するトリペプチドが見いだされている (Phaseolus radiatus から $\gamma$-Glu $\cdot \gamma$-Glu $\cdot$ methionine ${ }^{(25)}$, Fagus silvatica から $\gamma$-Glu. $\gamma$-Glu.phenylalanine $\left.{ }^{(8)}\right) . \quad P$. radiatus は多量の $r$-Glu·methionine を, F. silvatica は多量の $r$-Glu·phenylalanine を含んでいることから， それらジペプチドが $\gamma$-GT の作用に対し Glu 残基の供 与体と同時に受容体として働いた結果生ずると考えられ る. Allium cepa の発芽中の $\gamma$-Glu 誘導体の消失に $\gamma$ GT が働いていること ${ }^{(26)}$, Glycine max の発芽中の $\gamma$-Glu 誘導体の変 化とr-GT活性変化が一致している こと(27)などあ報告されている.

担子菌類に括いても，r-GTは $\gamma$ Glu 誘導体の合成上りも, むしろそ の分解関与していると考兄られる [4 章 4) 6) 参照].

Corynebacterium glutamicum によるグルタミン酸醱䤉の際に数種 の $\gamma$-Glu 誘導体が生ずる. その合 成機構は次のように解明されてい る(28).まず, $r$-Glu·glutamic acid が高濃度のグルタミン酸から加水分 解反応の逆反応により直接合成され， 次にペプチド転移により他の $\gamma$-Glu
誘導体が生成する.成熟中の植物種子のアミノ酸含量が 高い場合は，同様の過程が植物中でも起こる可能性があ る.

動物，微生物ではグルタチオンはダルタミン酸，シス テイン, グリシン，ATP より， 2 段階の反応で生合成 されることが明らかになっている。この 2 つの反応を触 媒する酵素, $\boldsymbol{r}$-glutamylcysteine synthetase および glutathione synthetase は植物中にも存在が知られて括 り，植物中でもグルタチオンの生合成は同じ経路で行な われると考兄られる，r-Glu 誘導体のあるものは上記の 醰素によって生ずる可能性もあるが，一方グルタチオン は必須の成分であり，その生合成系が他の多くの，特に 多量に存在する $r$-Glu 誘導体の形成にも関与している とは考光難い，植物に掓るグルタチオンの役割は，そ の酸化還元能に起因するものであるとされており，これ は他のほとんどの $\gamma$-Glu 誘導体には当てはまらない。 動物においてはアミノ酸の能動輸送に $\gamma$-Glu·cycle (下 図）の関与していることか゚ Meister ら ${ }^{(29)}$ の研究により 明らかにされているが, 植物ではアミ>酸の細胞膜通過 に関する研究は少なく，この cycle が植物で働いている か否かは不明である.この cycle に関与する醳素のう ち, $r$-glutamylcyclotransferase $と$-oxoprolinase の植物に执ける存在はまだ報告されていない。しかし， 植物中で 5-oxoproline は代謝的に不活性なるのではな く,グルタミン酸に変化することが知られている( ${ }^{(30)}$.

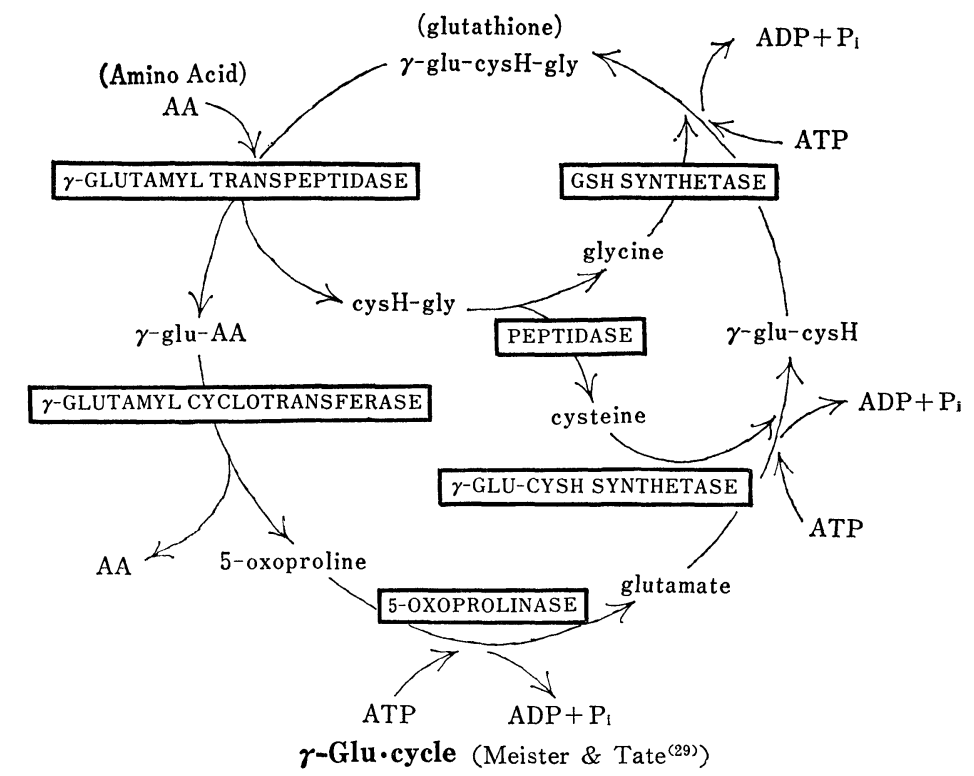

Vol. 17, No. 5 
アミン，特に低級脂肪族アミンの $r-$ Glu 誘導体の生 成には glutamine synthetase が関与している可能性が ある.しかし, 茶葉に著量存在するテアニン [4 章 7 )参 照]は glutamine synthetase とは異なる別の酵素によ って合成される(31). Lunaria annua の酵素調製品はグ ルタミン酸, エチルアミン, ATP からテアニンを合成 するが，この酵素は glutamine synthetase と考えられ る(32). な特, 同植物はテアニンを含有しないが, イソプ ロピルアミン特よびェタノールアミンの $\gamma$-Glu 誘導体 を含んでいる(33).

4. 代謝, 生理的意義, 作用などの判明している $\boldsymbol{r}$-Glu 誘導体

1) $\boldsymbol{\gamma}$-L-glutamyl- $\boldsymbol{\beta}$-cyano-L-alanine

この化合物は遊離の $\beta$-シアノアラニンとともにVicia 属㧊よび Lathyrus 属の多くの種の種子に存在する. $V$. sativa（カラスノエンドウ）の実生では $\gamma$-Glu 誘導体 が種子中よりもはるかに多いが， $r$-Glu 誘導体として存 在する $\beta$-シアノアラニン量は種子中の遊離および結合 型 $\beta$-シアノアラニン量の和に等しく, 発芽中の合成は 起こっていないと考えられる(34). V.sativa の成熟中の 種子ではセリンが遊離型および結合型の両方の $\beta$-シア ノアラニンにとり达まれる(35). V.sativaは $\beta$-シアノ アラニンをアスパラギンに代謝することはできないが， この変換を容易に行なう種では $r-G l u$ 誘導体含量はき わめて少量かあるいは存在しない. $\beta$ ーシアノアラニンは 遊離でも $r$-Glu 誘導体としてもラット，チキン，ヒト に毒性を示し, lathyrism と称する神経执よび骨格異常 をひき起こすことが知られている(36).

\section{2) $\mathbf{N}^{5}$-(2-cyanoethyl)-L-glutamine}

この $\gamma$-Glu 誘導体もラットに lathyrism をひさ起こ す物質として, Lathyrus odoratus 種子より単離され た(37).

\section{3）Allium 属中の含硫アミノ酸の $\boldsymbol{\gamma}$-Glu 誘導体}

Allium 属から多数の S-置換システインの $\gamma$-Glu 誘 導体が多くの場合遊離型とともに見いだされている.こ の属の植物は, S-置換 cysteine sulfoxide を解裂して 揮発性含硫化合物，ピルビン酸，アンモニアを生ずる C-S lyase を含んでおり， $\gamma$-Glu 誘導体は S-置換シス ティン類の貯蔵型としての役割を持っているのかもしれ ない. $r$-Glu 誘導体として Allium cepa (タマネギ)中
に多量存在する S-prop-1-enylcysteine sulfoxide(I) から C-S lyase の作用により生ずる propenylsulfenic acid（II）は, 同植物およびその他の Allium 属植物の 催涙性物質である. その他のシスティン誘導体より生ず る揮発性含硫化合物についても, 催涙物質, 香味物質, 抗生物質などとしての作用が報告されている ${ }^{(38)}[4$ 章4)， 5）参照].

S-置換システインはシスティンの SH 基と適当な 2 重 結合を持った化合物とより生ずる可能性がある、たと文 ば, Allium schoenoprasum (エゾネギ) 種子中に存在 する N, N-bis ( $\gamma$-glutamyl)-3, 3'-(1-methylethylene1,2-dithio) dialanine (III) は, 同種子中に存在する $r$ -

$$
\begin{aligned}
& \mathrm{CH}_{3} \mathrm{CH}=\stackrel{\mathrm{O}}{\mathrm{CHSCH}} \mathrm{CH}_{2}\left(\mathrm{NH}_{2}\right) \mathrm{COOH} \\
& \mathrm{CH}_{3} \mathrm{CH}=\stackrel{\mathrm{O}}{\mathrm{CHSH}} \\
& \text { II } \\
& \gamma \text {-Glu } \underset{\mathrm{NH}}{\mathrm{COOOH}} \gamma \text {-Glu } \cdot \underset{\mathrm{NHCH}}{\mathrm{COOH}} \\
& \mathrm{CH}_{2} \mathrm{SCH}_{2} \mathrm{CHSCH}_{2} \\
& \text { III }
\end{aligned}
$$

$\mathrm{Glu}$-cysteine と $\boldsymbol{\gamma}$-Glu.S-(prop-1-enyl)cysteine より 生ずるのではないかと考えられている（ただし，r-Glu・ cysteineは同種子からはジスルフィドとして同定されて。 (る) (39).

A. sativum (ニンニク) 中の $\mathrm{S}$-(2-carboxypropyl)glutathione 拈よび S-(2-carboxypropyl) cystein では, その S-置換基にバリンがとり込まれることから，ハリ ンが methacrylic acid に変化した後付加する, と考え られる(40).

4) 2 -( $\gamma$-glutamylamino $)-4,6,8,10,10$-pentaoxo4, 6, 8, 10-tetrathiaundecanoic acid (lentinic acid) $(\mathrm{IV})$

担子菌類の Lentinus edodes(シイタケ), Micromphale

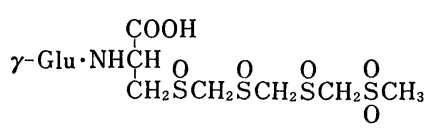
IV<smiles>C1SSCSSS1</smiles> 
perforans, Collybia hariolorum に含まれる lentinic acid は $\boldsymbol{\gamma}$-GT, 次いで C-S lyase の作用により, ホル ムアルデヒド, ピルビン酸, アンモニアの他, lenthionine (V) などの種々の揮発性含硫化合物を生ずる(41,42). lenthionine は Lentinus edodes に特徵的な香気を与光 る物質である.

5) $\boldsymbol{\gamma}$-L-glutamyl-3-(methylthiomethylsulfinyl)L-alanine ( $\boldsymbol{\gamma}$-glutamylmarasmine) (VI)

担子菌類 Marasmius species から単離されたこの化 合物は, lentinic acid の場合と同様に $\gamma-\mathrm{GT}$, 次いで CSlyaseの作用により不安定な化合物，おそらく methylthiomethylsulfenic acid (VI), さらに sulfinic ester （VIII)を経て種々の香気物質 $(\mathbb{X})$ を与える(43).

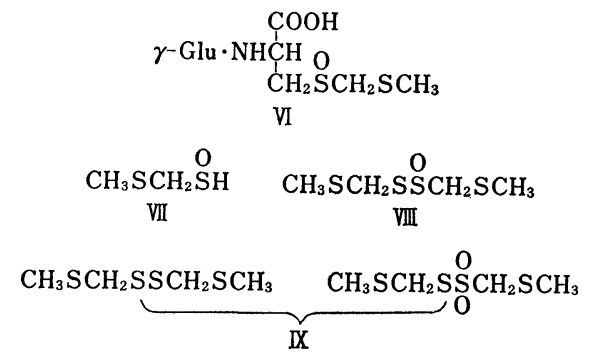

6) $\mathbf{N}^{5}$-(4-hydroxyphenyl)-L-glutamine (X), $\mathbf{N}^{5}$ (3, 4-dihydroxyphenyl)-L-glutamine (agaridoxine) (XI) および $\mathrm{N}^{5}$-(3, 4-dioxycyclohexa-1, 5-dien-1-yl)-

\section{L-glutamine (XII)}

この3つのペプチドは担子菌類 Agaricus より単離さ れたもので(44 46)，XをXII変換する tyrosinase 活性を 有する酵素も部分精製されている(45).XIはとの過程の中 間体と考えられる.インタクトな組織中では，この前駆 体と酵素は別々に存在している.XIIは SH 酵素の阻害剂 であり，殺菌性を有するまた， fungus spore の休止 状態を開始あるいは持続させると考えられている(47). XII は哺乳類の腫瘍細胞に対して cytostatic な効果を示 す(48). Xは，最近マッシュルーム Psalliota bisporus

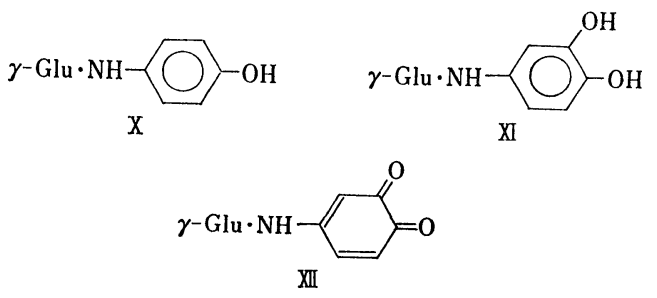

からヒトのリンパ細胞の blastgenation に対する阻害剂 として単離されている(49). A. bisporus 中でX, XIのア ミン部分に shikimate がとり込まれることが確かめら れている(50).

7） $\mathbf{N}^{5}$-ethyl-L-glutamine (テアニン) および $\mathbf{N}^{5}$ methylglutamine

Camellia sinensis (茶)の葉の乾物重の $1.7 \%$ を占め るテアニンは，それ自身执よびカテキンの前駆体として 茶の香味に重要な物質である. テアニン合成は主に根で 行なわれ(51)，グルタミン酸，エチルアミン，ATP より テアニンを生成する酵素が茶実生より得られている(31). エチルアミンはアラニンより L-alanine decarboxylase の作用で生ずる(52). テアニンは，分解によりそのエチル 部分が主にカテキンのフロログルシノール核にとり込ま れる.このとり达みは acetate を経由すると考光られる が, acetate はテアニンの代りにはならず，別のプール の存在が示唆される(53).

茶葉中には $\mathrm{N}^{5}$-methylglutamine も存在する.これ も根で合成されて苗条に移り，そこでメチル部分のほと んどがカフェインにとり込まれる(54).

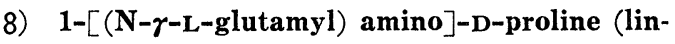
atine) (XII)

Linatine は Linum usitatissinum (亜麻) 種子より 単離されたビタミン $\mathrm{B}_{6}$ 拮抗剤で, チキン, Azotobacter などに対して毒性を示す.この毒性は pyridoxal-5'phosphate とヒドラท゙ンを形成することによるものであ $ろ^{(55)}$.

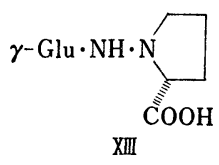

9) $\boldsymbol{\gamma}$-L-glutamyl-(2S, $\left.\mathbf{1}^{\prime} \boldsymbol{R}\right)-3$-(methylenecyclopropyl) alanine (Hypoglycine B) (XN)

Hypoglycine B およびA（BのC端アミノ酸）は Blighia sapida (アキー) の未熟果実より，その毒性执よ び低血糖作用の原因物質として単離された. この両化合<smiles>[3H][CH]N[C@H](C[C@H]1C[C@@H]1C)C(=O)O</smiles>

XIV 
物の毒性, 薬理学的性質についてはシンポジウム報告が ある(56).

10) $\boldsymbol{\gamma}$-L-Glutamyl-Se-methylseleno-L-cysteine このペプチドは Astragalus bisulcatus (ゲンゲ) 種 子の毒性の原因となる化合物で, C 端アミノ酸の遊離型 と共存している. 動物に対する毒性については総説があ る(57).

\section{1) $\mathbf{N}^{5}$-(1-hydroxycyclopropyl)-L-glutamine} (coprine) (XV)

Coprine は, マッシュルーム Coprinus atramenterius をアルコールと一緒に摂取したときに現われる毒性 の原因物質として単離された。 1-aminocyclopropanol 部分が coprine によるアセトアルデヒドレベルの in vivo に和ける上昇をひき起こすと考えられている(58).

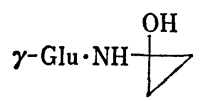

$\mathrm{XV}$

\section{2) $\boldsymbol{\gamma}$-L-Glutamyl-L-phenylalanine}

イエバエ Musca domestica の幼虫成長時に本化合物 は増加し続け，完全に成長した幼虫中で最高值に達する この時点でその $85 \%$ が血液中に存在する.このペプチ ドは, $\gamma-G T$ の作用によってグルタチオンとフェニルア ラニンより生合成される.この多量の本化合物も蛹の黒 硬化が始まると, 数時間の内にそのレベルは激減し, 8 時間後にはほとんど存在しない.この分解には，(1)5oxoproline と phenylalanine への分解, (2)加水分解, の 2つの反応が同時に関与しているが，初期には(1)が優勢 で, その後(2)が重要になってくる.こうして生じたフェ ニルアラニンが Musca 蛹の硬化の重要な前駆体となる. すなわち，このフェニルアラニンがメラニンおよび（あ るいは）キノンに代謝され，蛹化段階に拉ける cuticle protein のタンニングに働くと考えられている(59,60).

以上述べたわずかの例からみても， $\gamma-\mathrm{Glu}$ 誘導体すべ てに当てはまる一般的役割を考えることはできそうにな い. 植物中では $r$-Glu 誘導体は多くの場合, 種子, 塊 茎などの貯蔵組織中に多量含まれていることから，貯蔵 物質としての働きを有しているのかもしれない，種子中 の蛋白性アミノ酸の $\gamma$-Glu 誘導体含量が著しく多く, その種子の必須アミノ酸含量を定量する際に $r$-Glu 誘
導体含量も考慮しなければならない場合もある(18,61). 非 蛋白性アミノ酸の $\gamma$-Glu 誘導体については, 種子成熟 段階に非蛋白性アミノ酸が他の物質とともに種子中に移 行してくるため，種子は蛋白質にとり込むことのでさな い非蛋白性アミノ酸の增加に対処しなければならず，こ れを $\gamma$-Glu 誘導体に变換する，といら考方方がされて いる.これはまた解毒の機構でもあるかもしれない(62). しかし，この考え方が妥当であるとしても，植物が非蛋 白性アミノ酸を生産するといら事実，特よび $\gamma$-Glu 誘 導体にはっきりした分布パターンがあるという事実を説 明することはできない， $r$-Glu 結合は通常のペプチド結 合に比べて化学的にははるかに弱いが，それが生体内で も切れやすいといらことを意味しないのはもちろんで， むしろC端アミノ酸を貯蔵し，必要なときに必要な場所 に移行するまで分解を受けないための，通常の $\alpha$-ペプ チド結合を切る酵素などでははずされない保護基として r-Glu 結合が役立っているのではないだろうか。また， $\gamma$-Glu 誘導体は通常の $\alpha-ア ミ ノ$ 酸と同じ $\alpha$-zwitter ion 構造を有していること，および疎水性アミノ酸をC 端に有するものの分布が広いことも，特にその移動形態 としての役割を考学る上で重要なことと思われる。

自然界，特に植物から多数のアミノ酸およびアミンの $\gamma$-Glu 誘導体が報告されて括り，その数は非蛋白性のア ミノ酸の数が年々増加するのと同様に増え続えるである 5. $r$-Glu 誘導体の物理化学的性質については詳細な 記載(63,64) があるが，特に植物に打けるその代謝, 生理的 意義などについてはほとんど知られていない，それらに ついて，すべての $\gamma$-Glu 誘導体に当てはまる一般則を 期待することは無理と思われるが，個々の $r$-Glu 誘導 体の生理的意義の理解に近づくためにも，今後の研究の 発展に期待したい。

追記 : 本稿送付後, $\gamma$-GT の阻害剂として Penicillium oxalicum から 1-r-L-glutamy1-2-(2-carboxyphenyl) hydrazine (anthglutin) の単離が報告され $た^{(65)}$.

\section{文献}

1) S. G. Waley : Advan. Protein Chem., 21, 1(1966).

2) T. Kasai \& P.O. Larsen : Fortschr. Chem. Org. Naturst., in press. 
3) D. E. Nitecki \& J. W. Goodman : "Chemistry and Biochemistry of Amino Acids, Peptides and Protein", ed. by. B. Weinstein, Marcel Dekker Inc., New York, 1971. p. 87.

4) I. Kristensen, P. O. Larsen \& H. Sørensen : Phytochemistry, 13, 2803(1974).

5) L. Fowden : ibid., 11, 2271(1972).

6) C. J. Morris, J. F. Thompson \& S. Asen : J. Biol. Chem., 239, 1833(1964).

7) M. Fukuda, T. Ogawa \& K. Sasaoka : Biochim. Biophys. Acta, 304, 363(1973).

8) T. Kasai, P. O. Larsen \& H. S $\phi$ rensen : Phytochemistry, 17, 1911(1978).

9) D. J. Nugent : Diss. Abstr. Int. B, 31, 6471(1971).

10) R. R. Selvendran \& S. Selvendran:Ann. Bot. (London), 37, 453(1973).

11）金沢 彰: 生化学, 38, 346(1966).

12) K. L. Reichelt : J. Neurochem., 17, 19(1970).

13) D. L. Buchanan, E. E. Haley \& R. T. Markiw:Biochemistry, 1, 612(1962).

14) G. Dardenne, J.Casimir \& H.S $\phi$ rensen : Phytochemistry, 13, 1515(1974).

15) A. S. Seneviratne \& L. Fowden : ibid., 7, 1039(1968).

16) E. A. Bell : Biochem.J., 83, 225(1962).

17) E. A. Bell \& A. S. L. Tirimanna : ibid., 97, 104(1965).

18) E. Otoul, R. Marechal, G. Dardenne et F. Desmedt : Phytochemistry, 14, 173(1975).

19）葛西隆則, 佐野 実, 坂村貞雄 : 農化, 49, 313(1975).

20) R.P. Bodnaryk: Comp. Biochem. Physiol. B, 43, 587 (1972).

21）渡部俊夫, 志摩萬司, 市原輝子 : 北海道教育大学紀要 II A, 20, 76(1970).

22）渡部俊夫, 津川正明, 高山直正, 古川嘉克 : 同上, 22,45 (1971).

23) M.Y. Goore \& J.F. Thompson : Biochim. Biophys. Acta, 132, 15(1967).

24) J. Fujii \& M. Izawa: Agric. Biol. Chem., 31, 767 (1967).

25) T. Kasai, S. Sakamura, S. Inagaki \& R. Sakamoto : ibid., 36, 2621(1972).

26) S. Schwimmer \& S. J. Austin :J. Food Sci., 36, 807 (1971).

27) T. Kasai \& Y. Obata : Agric. Biol. Chem., 31, 127 (1967).

28) M. Hasegawa \& I. Matsubara : ibid., 42, 383(1978).

29) A. Meister \& S.S. Tate : Annu. Rev. Biochem., 45, 559 (1976).

30) M. Mazelis \& H. M. Pratt : Plant Physiol., 57, 85 (1976).

31) K. Sasaoka, M. Kito \& Y.Onishi : Agric. Biol.Chem., 29, 984(1965).

32) D.M. Frisch, P.M. Dunnill, A. Smith \& L.Fowden : Phytochemistry, 6, 921(1967).

33) P.O.Larsen : Acta Chem. Scand., 19, 1071(1965) ; 21, 1592(1967).

34) C. Ressler, Y.H. Giza \& S. N. Nigam : J. Amer. Chem. Soc., 91, 2766 (1969).

35) S. N. Nigam \& W.B. McConnell : Can. J.Biochem., 46, 1327(1968).

36) L. Fowden, D. Lewis \& H. Tristam : Advan. Enzymol., 29, 89(1967).

37) E. D. Schilling \& F.M.Strong : J.Amer. Chem. Soc., 77, 2843(1955).
38) A. I. Virtanen : Phytochemistry, 4, 207(1965).

39) E. J. Matikkala \& A.I. Virtanen : Acta Chem. Scand., 17, 1799(1963).

40) T.Suzuki, M. Sugii \& T. Kakimoto: Chem. Pharm. Bull., 10, 328(1962).

41) G. Höfle, R. Gmelin, H. Luxa, M. N'GalamulumeTrevesan \& S. Hatanaka : Tetrahedron Lett., 3129 (1976).

42) K. Yasumoto, K. Iwami \& H. Mitsuda : Agric. Biol. Chem., 35, 2070(1971).

43) R.Gmelin, H. Luxa, K. Roth \& G. Höfle : Phytochemistry, 15, 1717(1976).

44) A.Szent-Gyorgyi, R. H. Chung, M. J. Boyajiam, M. Tishler, R. H. Arison, E. F. Schoenwaldt \& J. J. Wittick : J.Org. Chem., 41, 1603(1976).

45) R.F. Weaver, K. V. Rajagopalan, P. Handler \& W. L. Byrne: J. Biol. Chem., 246, 2015(1971).

46) R.F.Weaver, K. V. Rajagopalan, P. Handler, D. Rosenthal \& P. W. Jeffs : ibid., 246, 2010(1971).

47) F.S. Vogel, S. J. McGarry, L. A. K. Kemper \& D.G. Graham : Amer. J.Pathol., 76, 165(1974).

48) F.S. Vogel, L. A. K. Kemper, S. J. McGarry \& D. G. Graham : ibid., 78, 33(1975).

49) T.Mouri, T.Murahara, H. Kayama, S. Tsutsui, T. Kurokawa, Y. Shibata, N. Ishida, S. Kakimoto, F. Asakura, H. Shirahama \& T. Matsumoto: Agric. Biol. Chem., 42, 2179(1978).

50）辻 英明, 板東紀子, 小川 正, 佐々岡啓 : 日本農芸化学 会昭和54年度大会要旨集, $4 \mathrm{E}-10, \mathrm{p} .436$.

51）小西茂毅, 葛西善三郎 : 日土肥，39，264(1968).

52) T. Takeo: Phytochemistry, 17, 313(1978).

53) M. Kito, H. Kokura, J. Izaki \& K. Sasaoka : Phytochemistry, 7, 599(1968).

54) S. Konishi, M. Ozawa \& E. Takahashi : Plant Cell Physiol., 13, 365(1972).

55) H. Tsuji, K. Moritoki, T. Ogawa \& K. Sasaoka : Agric. Biol. Chem., 41, 1413(1977).

56) "Hypoglycine", PAABS Symposium Series 3. ed. by E. A.Kean, Academic Press, 1976, p. 183.

57) J. L. Martin : "Selenium Assimilation in Animals. In Organic Selenium Compounds: Their Chemistry and Biology", ed. by D. L. Klayman and W.H.H. Günther, Wiley, New York, 1973, p. 663.

58) O. Tottmar \& P. Lindberg : Acta Pharmacol. Toxicol., 40, 476(1977).

59) R.P. Bodnaryk \& J. R. Skillings : Insect Biochem., 1, 467(1971).

60) R. P. Bodnaryk : J. Insect Physiol., 16, 919(1970); Insect Biochem., 4, 439(1974).

61) T. Kasai, S. Sakamura \& R. Sakamoto : Agric. Biol. Chem., 35, 1607(1971).

62) S. N. Nigam \& W.B. McConnel : Biochim. Biophys. Acta, 192, 185(1969).

63) T. Kasai \& S. Sakamura :J.Fac. Agric. Hokkaido Univ., 58, 283(1975).

64) T. Ogawa : Bull. Res. Inst. Food Sci. Kyoto Univ., No. 37, 1(1974).

65) S. Minato: Arch. Biochem. Biophys., 192, 235 (1979). 